\title{
Microglial Phagocytosis-Rational but Challenging Therapeutic Target in Multiple Sclerosis
}

\author{
Maria V. Pinto ${ }^{1}([)$ and Adelaide Fernandes $1,2, * \mathbb{C}$ \\ 1 Neuron-Glia Biology in Health and Disease, Research Institute for Medicines (iMed.ULisboa), Faculty of \\ Pharmacy, Universidade de Lisboa, 1649-003 Lisboa, Portugal \\ 2 Department of Biochemistry and Human Biology, Faculty of Pharmacy, Universidade de Lisboa, \\ 1649-003 Lisboa, Portugal \\ * Correspondence: amaf@ff.ulisboa.pt; Tel.: +351-217946400
}

Received: 1 August 2020; Accepted: 17 August 2020; Published: 19 August 2020

\begin{abstract}
Multiple sclerosis (MS) is the most common autoimmune and demyelinating disease of the central nervous system (CNS), characterized, in the majority of cases, by initial relapses that later evolve into progressive neurodegeneration, severely impacting patients' motor and cognitive functions. Despite the availability of immunomodulatory therapies effective to reduce relapse rate and slow disease progression, they all failed to restore CNS myelin that is necessary for MS full recovery. Microglia are the primary inflammatory cells present in MS lesions, therefore strongly contributing to demyelination and lesion extension. Thus, many microglial-based therapeutic strategies have been focused on the suppression of microglial pro-inflammatory phenotype and neurodegenerative state to reduce disease severity. On the other hand, the contribution of myelin phagocytosis advocating the neuroprotective role of microglia in MS has been less explored. Indeed, despite the presence of functional oligodendrocyte precursor cells (OPCs), within lesioned areas, MS plaques fail to remyelinate as a result of the over-accumulation of myelin-toxic debris that must be cleared away by microglia. Dysregulation of this process has been associated with the impaired neuronal recovery and deficient remyelination. In line with this, here we provide a comprehensive review of microglial myelin phagocytosis and its involvement in MS development and repair. Alongside, we discuss the potential of phagocytic-mediated therapeutic approaches and encourage their modulation as a novel and rational approach to ameliorate MS-associated pathology.
\end{abstract}

Keywords: demyelinating lesions; microglia; myelin phagocytosis; multiple sclerosis; therapeutic strategies

\section{Introduction}

Multiple sclerosis (MS) is the primary chronic autoimmune, demyelinating disease of the central nervous system (CNS), and the most debilitating condition in young adults aged between 20 and 45 years [1]. It is mostly accepted, nowadays, that a dysregulation of the inflammatory response against myelin components-genetic and/or environmentally-mediated-leads to the recruitment of peripheral autoreactive $\mathrm{T}$ and $\mathrm{B}$ cells and macrophages across the blood-brain barrier (BBB). Reactivation of such immune cells within the CNS induces a potent inflammatory response with cytokine and chemokines' release that further activates other immune cells (e.g., dendritic cells) and local microglia causing myelin to degenerate around the nerve axons. Myelin loss then leads to the subsequent formation of the MS-characteristic demyelinated plaques associated with axonal damage and neurodegeneration that clinically translates into initial relapses evolving with time into progressive disability of motor, visual, and cognitive functions, essentially [2-6]. 
MS prevalence and impact in life quality together with the significant financial burden either on the patient, society, and healthcare system potentiated the extensive demand and success of some therapeutic approaches using disease-modifying drugs approved because of their efficacy to reduce relapse rate and slow disease activity and progression $[7,8]$. Based on the above described autoimmune nature of MS, these immunomodulatory drugs either target $\mathrm{T}$ cell proliferation (interferon-beta) [9], immune cell activation and inflammatory response (interferon beta, glatiramer acetate) $[10,11]$, or the peripheric invasion of autoreactive $T$ and $B$ cells: Preventing the ability of these cells to egress from the lymph nodes (fingolimod) [12]; or inhibiting their crossing over the BBB (natalizumab) [13,14]. Further revolutionary, cell-depleting drugs (e.g., alemtuzumab, ocrelizumab) $[15,16]$ were also approved potentiating either the depletion of autoreactive lymphocytes or CD20-expressing B cells only, respectively, therefore modulating immune response through immune repopulation. Yet, they all failed to restore CNS myelin and to fully prevent MS disability.

Regarding MS recovery, current studies have been focused on remyelination, which is a biological regenerative process that restores myelin around denuded axons and has been documented in experimental models and acute MS lesions following inflammatory-mediated demyelination. Here, oligodendrocyte (OL) precursor cells (OPCs) are spontaneously recruited to the lesioned region, differentiating into myelinating OLs to restore myelin sheaths and protect them from further degeneration [17-19]. However, despite the presence of functional OPCs, the majority of lesioned areas with progressive demyelination in MS fail to remyelinate [20-22]. As an attempt to find remyelinating therapies only, clemastine fumarate validated its efficacy on remyelination in clinical trials by promoting OPC differentiation in chronic demyelinating lesions of MS [23], for which there is the need for other candidates to rescue MS lesions from progressive degeneration.

Microglia, the resident immune cells and macrophages of the CNS, make up only $15 \%$ of the total brain cells [24] and $10 \%$ of whole glial cells $[25,26]$. Nonetheless, due to their essential functions as immune mediators and primary phagocytes of the brain and spinal cord, microglia have attracted much attention and research. This yolk sac-derived population colonizes the brain during embryogenesis and differentiates under the influence of CNS microenvironment [27], residing in the healthy nervous system as a highly stable population with long and ramified processes interacting with blood vessels, neurons, and other glial cells in a dynamic "surveillant state" [28]. "Surveillant" microglia maintain CNS homeostasis by sensing pathologic events, scavenging pathogen-associated molecular patterns (PAMPs)/danger-associated molecular patterns (DAMPs), and by phagocytosing dead cells and misfolded proteins $[29,30]$. At the same time, in physiological conditions, they are also engaged in the regulation of biological processes either remodeling synaptic plasticity [31,32], supporting neuronal survival [33], brain sexual differentiation [34,35], or promoting proper myelination [36-38].

In response to any insult or alteration in brain homeostasis, these highly sensitive glial cells migrate and accumulate at the lesioned area, through a process of chemotaxis, and become activated to initiate the innate immune response. Profound morphological and molecular changes accompany microglial activation (Figure 1): Cells suffer partial retraction of their processes evolving from a ramified state, to an intermediate one or "Bushy" and finally converting into a complete rod and amoeboid shape or fully activated state $[39,40]$. Parallel to their morphological transformation, activated microglia express a characteristic genetic profile with an elevated expression of ionized calcium-binding adaptor molecule-1 (Iba-1), major histocompatibility complex antigen class II (MHC-II), and microglial phagocytic markers such as CD11b, Fc receptors I-III, complement receptors, and CD68 [41,42]. Alongside, functional plasticity allows these reactive/activated microglia to differentiate into either neurotoxic or neuroprotective phenotypes associated with the release of both pro- and anti-inflammatory mediators and cytokines, respectively. Given their wide range of functions, microglia participate in the overall brain development and formation of a functional nervous system and have also been extensively described under several pathological conditions [43-45]. Particularly, in MS lesions, microglia account for the main inflammatory cells present, therefore strongly influencing demyelination and plaque recovery. Alongside, the unbalance between opposed phenotypes of microglia (with overactivation 
of these cells into their pro-inflammatory status) accounts for disease development and progression, and correlate with the clinical decline, whereby we believe that the development of therapies targeting microglia will likely define another milestone in MS remyelinating therapeutics [46-48].

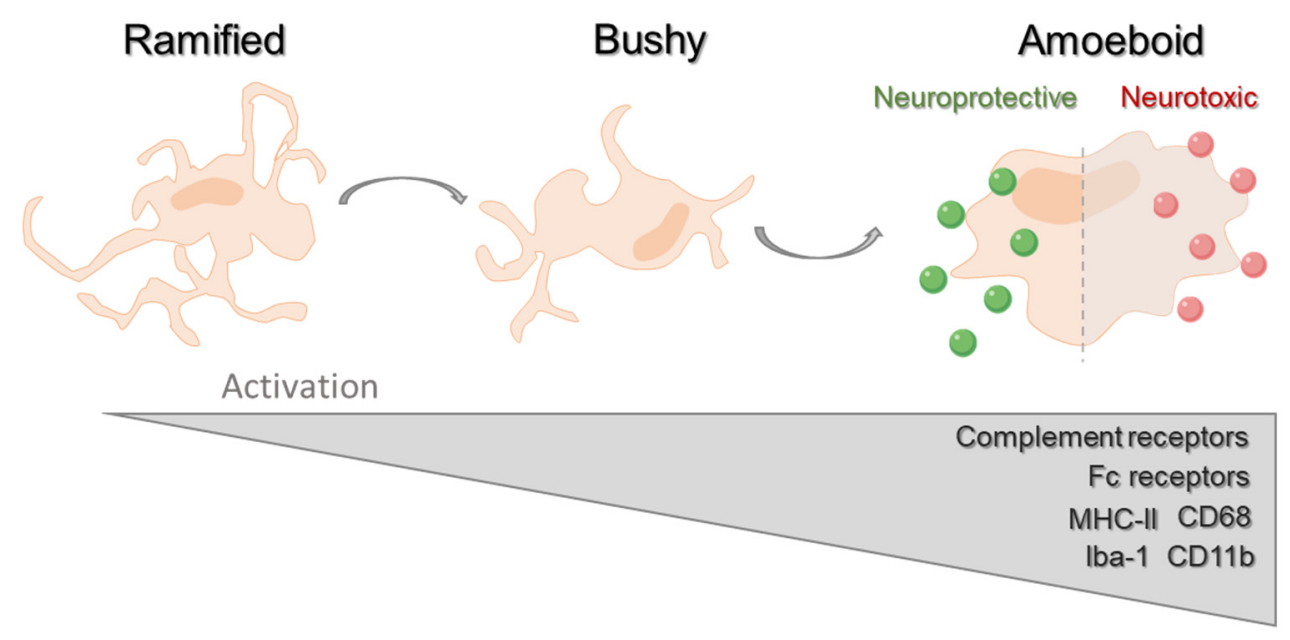

Figure 1. Schematic representation of microglial activation. Following any insult or alteration in brain homeostasis microglia become activated. Morphologically, cells partially retract their processes evolving from a ramified state, to an intermediate one or "bushy" and finally converting into a complete rod and amoeboid shape or fully activated state. In parallel, activated microglia overexpress specific characteristic markers such as ionized calcium-binding adaptor molecule-1 (Iba-1), major histocompatibility complex antigen class II (MHC-II), and microglial phagocytic markers such as CD11b, complement and Fc receptors I-III, and CD68. Finally, these activated cells can evolve into functionally distinct phenotypes either becoming neurotoxic or neuroprotective-reactive states associated with the release of both pro- and anti-inflammatory mediators and cytokines, respectively.

Indeed, emerged microglia-based therapeutic strategies have been mostly focused on the suppression of microglia-mediated inflammatory response and oxidative damage. Current research focused on anti-inflammatory molecules such as naringenin [49,50], ethyl pyruvate [51], and forskolin [52] envisioning regenerative approaches in MS by reducing microglial activation. Alongside, pre-clinical testing with a new vaccine, PADRE-K v1.3 [53], resulted in a decrease of pro-inflammatory microglia, in time replaced by an anti-inflammatory/regenerative population, alleviating clinical severity and pathological damages in a mice model of MS-experimental autoimmune encephalomyelitis (EAE). Furthermore, long noncoding RNA growth arrest-specific 5 (GAS5) that is highly expressed on amoeboid/activated microglia in MS lesions inhibits microglial polarization into a regenerative phenotype. Recent approaches on transplantation microglia with GAS5 interference ameliorated the EAE outcome, favoring as well axonal remyelination after LPC-induced demyelination [54]. Overall highlighting the experimental success of modulating the inflammatory role of microglia to rescue phenotypic unbalances (reviewed in $[55,56]$ ).

Nonetheless, remyelination failure also relies on the excessive accumulation of fragmented myelin-toxic debris in the extracellular space after prolonged demyelination, which significantly inhibits OPC differentiation. As so, apart from their crucial immune role in MS progression, clearance of myelin debris through microglial phagocytosis is required for tissue repair and critical in the progress of demyelinating diseases $[57,58]$. Whereas the microglial immunomodulatory role regarding MS has been extensively reviewed over the years, their contribution to MS disease progression as professional phagocytes, as well as therapeutic opportunities towards modulation of phagocytosis have been less explored. Therefore, in this review, we focus on the microglial phagocytic role throughout brain development and with a particular focus on MS-disease course, highlighting some molecules 
and targets with the potential to increase myelin clearance for disease amelioration but mostly for MS recovery.

\section{Microglial Phagocytosis}

Within the CNS, phagocytosis is mainly attributed to the specialized microglial cells, although other cells may slightly contribute (e.g., astrocytes, invading monocytes, and neutrophils). Microglial cells recognize, engulf, and digest large particles/structures, a process that is critical both in development, to remove apoptotic, excessive newborn cells, or unwanted synapses, and in pathology by clearing invading bacteria, cell debris, or degenerated myelin [59]. Indeed, microglial phagocytosis goes beyond brain refinement in physiologic conditions. It is critical in pathological conditions such as MS. Therefore, we will first address the microglial phagocytosis relevance during neurodevelopment and afterwards, the microglial phagocytic role in MS-like pathogenesis. Then, we will shed light on some promising phagocytose-based therapeutic strategies that could counteract MS disease burden, prevent demyelination, or even promote full disease recovery through remyelination.

\subsection{Microglial Phagocytosis during Neurodevelopment}

In the developing brain, non-activated microglia continuously survey the brain's environment, making frequent but transient contacts with neurons and synapses in response to neuronal activity [60]. Neuronal expression of fractalkine (CX3CL1) as well as their release of ATP/ADP function as "find me" signals that will interact with microglial fractalkine (CX3CR1) and purinergic receptors (P2Y12), respectively, and guide them towards active synapses [61-63]. However, microglia not only rely on the vicinity of neurons and synapses. Instead, they are fundamental in the process of synaptic plasticity and proper refinement of neural networks through synaptic pruning: An activity-dependent developmental program in which microglia eliminate (through phagocytosis) supernumerary synaptic connections over CNS development [64,65]. Otherwise, deficiencies in synaptic pruning correlate with developmental abnormalities [66,67] and impaired social behavior [68].

Studies from Paolicelli et al., using stimulated emission depletion (STED) microscopy, illustrated the microglial direct role on the engulfment of pre- and post-synaptic components in a healthy brain [61], further confirmed in subsequent studies from Schafer et al. Using high-resolution confocal imaging, the authors found either microglial processes in close contact with pre-synaptic inputs of retinal ganglion cells or these synaptic partners internalized into microglial soma [65]. Interestingly, from in vivo studies, authors concluded microglial preferential removal of weaker synaptic inputs that were tagged by complement proteins $\mathrm{C} 1 \mathrm{q}$ and $\mathrm{C} 3$, as deficient mice for either one of the latter complement proteins exhibited extensive defects in synaptic connectivity $[65,69,70]$. Yet, despite the involvement of complement cascade in neuronal elimination and pruning of synapses, other microglial receptors also play a role, such as CX3CR1 and triggering receptor expressed on myeloid cells 2 (Trem2) [71,72]. Particularly, Trem2 depletion on mice impaired not only cell migration towards hippocampal synapses but also synaptic internalization into CD68+ phagolysosomal structures. Furthermore, results from Trem2-/- old mice correlated with brain impaired functional connectivity between prefrontal and hippocampal regions and behavioral defects [72], as expected given the close association between phagocytosis and synaptic pruning with proper brain wiring, development, and function.

Additionally, the extensive cell turnover through apoptosis during brain development is again an important step for creating homeostasis and generating a functional brain. For that to be accomplished, cellular apoptosis drives microglial colonization and establishment in the CNS for a coordinated and efficient system of clearance/removal of apoptotic bodies by microglia, whereas inefficient phagocytosis of apoptotic bodies results, instead, in subsequent cell death alongside with inflammatory and immune responses because of the released intracellular contents [73,74]. Microglia are essential to remove apoptotic neural progenitor cells within the neurogenic niches of the hippocampus-subgranular and subventricular zones-via activation of TAM receptor tyrosine kinases MerTK and AXL [75], but also 
mediated by the complement system, as the $\mathrm{C} 1 \mathrm{q}$ complement protein was recently found expressed on microglial phagocytic pouches during hippocampal neurogenesis [76]. Apart from the hippocampus, microglia also phagocytosed apoptotic Purkinje neurons, for the proper maturation of rat cerebellum and correct development of the retina in zebrafish, a process that is surprisingly delayed after inhibition of microglial purinergic receptor P2RY12, thus unveiling an additional role of purinergic signaling in developmental phagocytosis of apoptotic cells $[74,77]$. On the other hand, current studies on microglia associate cell phagocytosis with the brain's sexual differentiation. Estradiol release in the female's brain enhances the number of phagocytic microglia (observed by the observed augment of phagocytic cups), thus increasing the removal of neural progenitor cells in the neonatal female hippocampus. As expected, differences in the remaining neuronal progenitors resulted in developmental alterations, namely in the hippocampal neuronal wiring and excitatory circuits. Nelson et al. even speculated if such differences in phagocytosed products could account for functional disparities between males and females [34]. Alongside, phagocytosis is also involved in the sexual differentiation of the amygdala. Testosterone-mediated enhancement of 2-arachidonoylglycerol in the brain activates type-1 and -2 cannabinoid receptors in microglia that will increase cell phagocytic cups, resulting in the observed reduction of newborn astrocytes over the first postnatal week. By regulating astrocytic density, in a complement-dependent manner, microglia lead to an increased neuronal excitation and masculinization of juvenile social play, distinct from female behavior [35].

Altogether, these functional dynamics of microglial phagocytosis emphasize their importance in the overall brain development, maintaining functional homeostasis, controlling neuronal progenitors, and strengthening synaptic connections for proper brain connectivity and wiring.

\subsection{Microglial Phagocytosis in Multiple Sclerosis: From Targets to Therapeutic Strategies}

\subsubsection{Phagocytosis and Myelin Clearance}

In MS, accumulation of chemokines, such as CXCL10, within demyelinated lesions function as chemoattractant molecules for microglia to migrate towards these regions where these cells will be responsible for the clearance of myelin-derived toxic debris. Nogo-A, oligodendrocyte-myelin glycoprotein, and myelin-associated glycoprotein are myelin-derived proteins and strong inhibitors of neurite growth, axonal regeneration, but most importantly, inhibitors of OPC differentiation into mature OLs and, by doing so, impair remyelination, which makes myelin clearance essential to initiate lesion repair [78-80]. The complement system is a well-described mechanism for the clearance of opsonized myelin as proteins of the complement bind to debris and control their interaction with complement receptor 3 (CR3) [81,82]. In addition to CR3, the microglial scavenger receptor AI/II (SRAI/II) can also recognize lipid debris and, when functioning together with CR3, even enhances complement-dependent myelin clearance by these cells [82]. Moreover, myelin also interacts with microglial MerTK, Trem2, and CX3CR1 receptors. Indeed, monocyte-derived macrophages from MS patients, with decreased expression of MerTK receptors, showed a reduced ability to clear myelin debris. On the other hand, Trem2-/- microglia not only lead to deficiencies in myelin removal but also in lipid metabolism, expression of inflammatory mediators, and trophic factors resulting in an augment of axonal dystrophy, oligodendrocyte reduction, and persistent demyelination in mice after cuprizone treatment [83]. Concordantly, mice treated with the anti-Trem 2 antibody worsened EAE outcomes (high clinical scores), increased inflammatory response, and demyelination in the brain parenchyma [84]. Additionally, CX3CR1 deficiency in mice reduced significantly the clearance of myelin and inhibited proper remyelination after cuprizone treatment accentuating the association between myelin clearance and demyelination/degenerative mechanisms $[58,85,86]$. For this reason, skewing research approaches to modulate microglia towards a more phagocytic state offer promising alternatives envisioning a long-term MS treatment.

New compounds, in non-clinical testing, revealed some encouraging effects regarding microglial phagocytosis (Figure 2A). To begin with, studies from Chen et al. found that the incubation of 
primary microglia with two omega-3 polyunsaturated fatty acids-docosahexaenoic acid (DHA) and eicosapentaenoic acid (EPA) - modulated the cell phenotype towards a more regenerative state and enhanced myelin phagocytosis in vitro. Attractively, such treatment in vivo reduced demyelination and ameliorated motor and cognitive functions in a cuprizone demyelinating model [87]. Additionally encouraging, a human recombinant IgM antibody (rHIgM22) effectively modulated microglial myelin phagocytosis. Indeed, in vitro testing showed that rHIgM22 could bind to myelin, tagging debris for their internalization by microglia, in a complement-mediated manner [88], and, when administrated in vivo, rHIgM22 promoted OPC differentiation, accelerated remyelination, and even ameliorated memory deficits in rodent models of cuprizone and chronic virus-induced demyelination [89-91]. Giving this newly association between phagocytosis and microglial neuroprotective functions over brain pathologies, two more studies concerning modulation of microglial phagocytosis have just been published. In the first one, the authors treated rat microglial cells with endocannabinoid 2-AG. By enhancing the mRNA levels of phagocytosis associated genes ( $\operatorname{cd} 206, \operatorname{sirp} 1 \alpha, \mathrm{msr} 1$, and Trem2), endocannabinoid 2-AG boosted phagocytosis of both Coli-coated beads and rat-purified myelin debris. Moreover, using a mice model of MS, the Theiler's induced demyelinating disease model (TMEV-IDD), TMEV-induced mice treated with endocannabinoid 2-AG showed augmented microglial myelin phagocytosis in the corpus callosum that likely resulted from the observed upregulation of msr1 and Lamp1 mRNA levels, genes associated with microglial phagocytic machinery and phagosome formation, respectively. Interestingly, these animals had increased OPC differentiation and remyelination following demyelination in the corpus callosum [92]. In the second study, Liu et al. observed that a new pharmacological treatment with pseudoginsenoside-F11 accelerated CR3-dependent myelin phagocytosis in a microglial culture after oxygen-glucose deprivation (OGD) and permanent middle cerebral artery occlusion (pMCAO) in vivo and, by doing so, decreased de infarct area and improved neurological functions in pMCAO-treated rats [93].

These revolutionary approaches towards microglial-targeted therapies open novel windows of opportunity for MS remyelination assessment, for what other molecules should be taken into account in future MS-related experiments. It is described that the activation of peroxisome proliferator-activated receptor $\gamma(\operatorname{PPAR} \gamma)$ in microglia suppresses the release of inflammatory mediators [94]. However, activation of PPAR $\gamma$ using both agonists: Pioglitazone and DSP-8658, also overexpresses the scavenger receptor CR36 and, while doing so, enhances microglial phagocytosis of Amyloid- $\beta$ (A $\beta$ ) in primary microglial cell culture and in vivo using a mouse model of Alzheimer's Disease (AD) [95]. Moreover, Yamanaka et al. reported a reduction of $A \beta$ in the cortex and hippocampus, accompanied by improved spatial memory in treated mice, given this improved phagocytosis [96]. Another PPAR $\gamma$ agonist (ursolic acid (UA)), significantly decreased disease severity, CNS inflammation, demyelination, and promoted myelin repair through remyelination in both acute and chronic stages of the disease in EAE-induced and cuprizone-treated mice [97]. Whether the PPAR $\gamma$-mediated effect of UA favor myelin phagocytosis by microglia among demyelinated lesions is unknown. However, we may postulate that once being upstream of the CD36 receptor that is also involved in the internalization of lipids and cholesterol-rich debris, PPAR $\gamma$ signaling may also interfere with cell phagocytosis and with the observed neuroprotective outcome on oligodendrocyte maturation and myelin regeneration following UA administration in vivo. On the other hand, treatment with nicotine or galantamine, this latter being an FDA approved acetylcholinesterase inhibitor for the symptomatic treatment of $\mathrm{AD}$ [98], significantly induced phagocytosis of extracellular toxic $\mathrm{A} \beta$ both in rat microglia and rodent models of AD. By sensitizing microglial nAChRs to choline and promoting calcium influx, galantamine and nicotine induced calcium-dependent massive actin reorganization favoring $A \beta$ internalization, accompanied by improvements in spatial learning and memory performance. Therefore, one can speculate that galantamine-mediated phagocytic effects may also underlie its previously described benefits in $\mathrm{AD}[98,99]$, and may have an important role in myelin clearance following demyelination. 


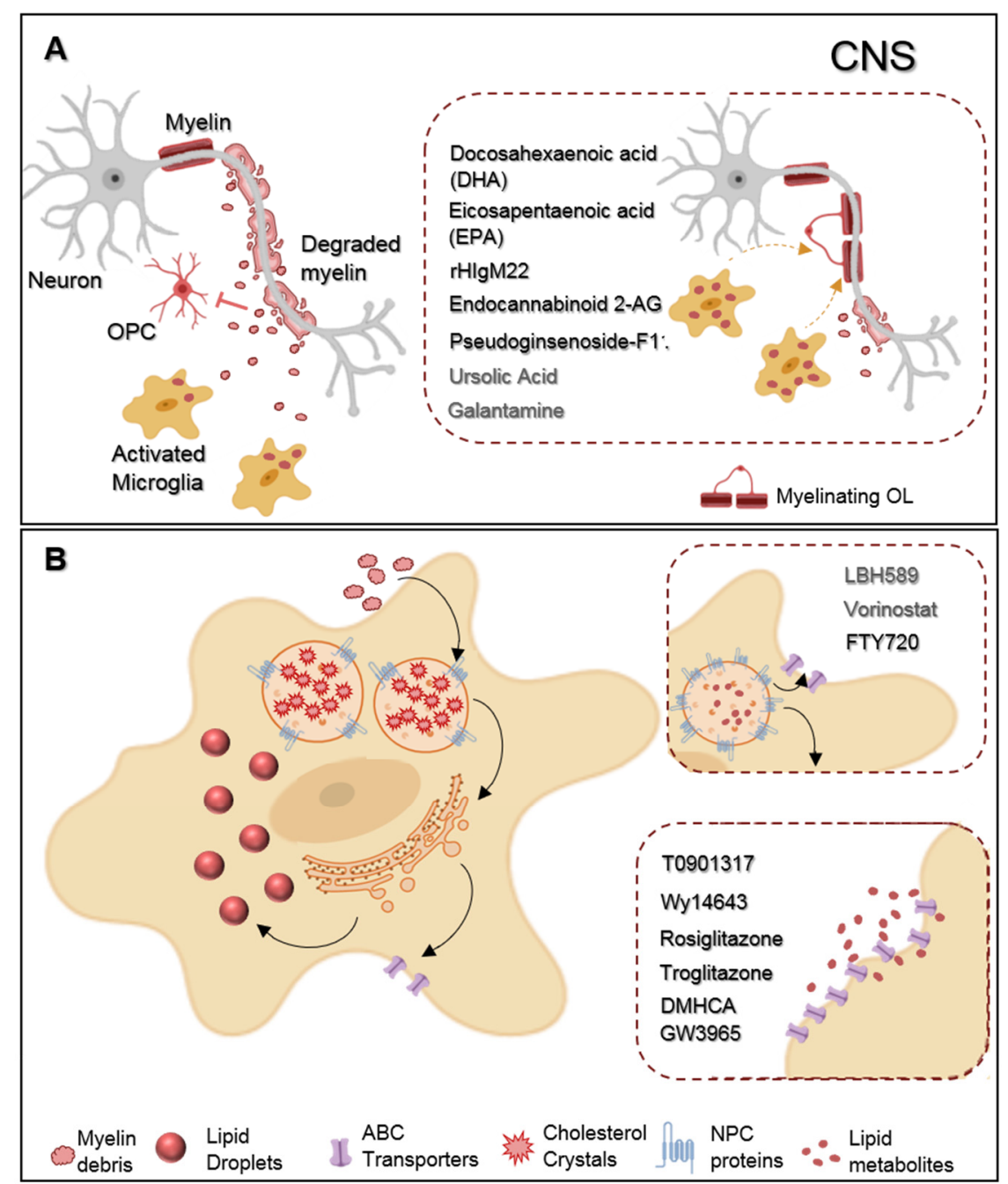

Figure 2. Representative scheme of microglia myelin phagocytosis modulating drugs. (A) During multiple sclerosis (MS) progression myelin is degraded into myelin-toxic debris within demyelinated plaques in the central nervous system (CNS). Giving debris toxicity towards oligodendrocyte (OL) precursor cells (OPCs) inhibiting their differentiation into full differentiated myelinating OLs, myelin debris must be cleared away by microglia. Regarding therapeutics, docosahexaenoic acid (DHA) and eicosapentaenoic acid (EPA) increase myelin uptake by microglia. Endocannabinoid 2-AG favors both myelin microglial clearance and OPC differentiation. Pseudoginsenoside-F11 accelerates CR3-dependent myelin phagocytosis while rHIgM22 binds to myelin debris and also facilitates their entrance towards microglia. Galantamine increases microglial uptake of $A \beta$ aggregates and ursolic acid can interfere in the upstream regulation of CD36 expression, so that they may likely have an effect on myelin phagocytosis. (B) Demyelinated lesions are associated with foamy phagocytes presenting a pro-inflammatory profile as a result of over-internalization of cholesterol-rich myelin debris. Intracellularly, excessive cholesterol dysregulates lipid metabolism and efflux pathways and accumulates in the lysosomes forming cholesterol crystals or can be stored into lipid droplets. Proposed therapeutics are based on the functionalization of lipid metabolism and associated pathways. LBH589 and Vorinostat increase the expression of NPC proteins in fibroblasts, facilitating cholesterol release from lysosomes, for what we envision a possible effect on microglia as well. FTY720 treatment lead to the overexpression of both NPC and ABC transporters also promoting lipid efflux from human primary macrophages. DMHCA and GW3965 directly or Wy14643, Rosiglitazone, and Troglitazone, indirectly, activate the LXR/RXR heterodimeric transcription factor which upregulates its transcriptional targets $\mathrm{ABC}$ transporters then again facilitates cholesterol/lipid exit from macrophages. 


\subsubsection{Phagocytosis and Microglial Inflammatory Profile}

The phagocytic process increases in complexity when the entrance of a large metabolic load from digested targets alters microglial intracellular pathways and metabolism. Particularly in MS, myelin by itself is a potent inflammatory stimulus so that its interaction with membrane receptors and further internalization can interfere with functional phenotypes of microglia and influence MS inflammatory responses, as reviewed by Grajchen et al. [100]. Whereas myelin entrance through the C3/CR3 axis initiates a subsequent inflammatory signaling cascade with the expression of neurotoxic cytokines and inflammatory modulators (via activation of the NF-kB signaling cascade) [101,102], Trem2-mediated myelin recognition, on the contrary, activates downstream anti-inflammatory pathways in response to demyelinating stimuli $[83,84,103]$. Subsequentially, over the course of myelin intracellular processing, activation of heterodimeric transcription factor, liver $X$ receptor (LXR)-retinoid $X$ receptor $(\mathrm{RXR})$, and $(\mathrm{PPAR} \beta / \delta)$ by myelin-derived cholesterol and phosphatidylserine residues, respectively, leads to downstream anti-inflammatory responses [104-106]. This being in line with the observed anti-inflammatory lipid-engorged (foamy) microglia within MS resolving lesions, preferentially expressing anti-inflammatory molecules and inducing $\mathrm{T}$ cell-mediated anti-inflammatory adaptative immune responses, even capable of reducing EAE severity [107,108].

Nonetheless, other studies describe the presence of pro-inflammatory and neurodegenerative foamy macrophages within MS lesions suggesting functional plasticity of these myelin-loaded cells [2]. Within foamy cells, myelin entrance is followed by lipid metabolization into myelin-derived free/unesterified cholesterol in the lysosomes. The toxicity of intracellular accumulation of free cholesterol requires their transportation, facilitated by lysosome membrane proteins such as Niemann-Pick type disease C (NPC) 1 and 2, to the endoplasmic reticulum for a process of esterification into cholesterol esters that will be posteriorly effluxed from the cell via ATP-binding cassette (ABC) transporters, or stored into lipid droplets [109], as depicted in Figure 2B. Despite the above correlation of myelin intracellular metabolization with an anti-inflammatory phenotype of microglia, it is observed that the uncontrolled entrance of cholesterol-rich lipids dysregulates degradation mechanisms as well as lipid storage and efflux pathways. Excessive intracellular lipids accumulated in unesterified forms within microglial membrane (lipid rafts) activate inflammatory responses through TLR and NF-kB signaling pathway [110]. Alongside, higher concentration of free cholesterol in the lysosomes ultimately form cholesterol crystals, inductors of lysosomal damage, and activators of NLRP3 inflammasome that consequently produce and release IL- $1 \beta$ and IL-18 inflammatory cytokines, as described in other inflammatory diseases (e.g., atherosclerosis) [111]. Concordantly, a distinct microglial subpopulation, the lipid-droplet accumulating microglia (LDAM), with dysfunctional intracellular lipid deposits was recently identified in the aging brain and similarly presented a unique transcriptional signature with increased production of pro-inflammatory cytokines, elevated levels of reactive oxygen species (ROS), and phagocytic deficiencies which ultimately reinforces previous research associating lipid disturbances with microglial pro-inflammatory shift [112]. In MS, the microRNA analysis profile from demyelinated lesions revealed the upregulation of microRNAs 34a, 155, and 326 inhibitors of myelin expressed "don't eat me" protein CD47, the one that prevents macrophage activity through its interaction with the microglial receptor SIRP $\alpha[113,114]$. Dysregulation of microRNA profile, upregulation of myelin microglial receptors within demyelinated areas together with the enormous amount of degraded myelin extracellularly accumulated over chronic demyelination can facilitate excessive and continuous myelin uptake with consequent formation of dysfunctional foamy microglia [113,115-117]. In line with this, not only myelin clearance improves disease recovery, but researchers have also tried to modulate cholesterol metabolism, accumulation, and intracellular transportation in order to prevent lipid-mediated harmful microglia response.

To begin with, studies show that heterodimeric transcription factor LXR-RXR is involved in the regulation of cholesterol balance and metabolism in the brain through transcriptional upregulation of its target gene ABCA1 [117]. Cantuti-Castelvetri et al. using a lysolecithin-induced demyelinating model, observed that old mice failed to resolve the inflammatory response and had limited restoration 
and remyelination capacity due to their decreased ability to phagocytose myelin debris alongside their abnormal accumulation of cholesterol crystals. However, when treated with the GW3965 molecule, an agonist of the transcription factor LXR, the authors observed ameliorated lipid efflux, enhanced lesion repair, and decreased microglial activation in old mice, which strongly supports the finding of new molecules targeting myelin degradation pathways to reduce cholesterol/lipid accumulation and lysosomal dysfunction for MS therapeutics [118]. Similar to GW3965, other LXR agonists, T0901317 and $\mathrm{N}, \mathrm{N}$-dimethyl-3 $\beta$-hydroxy-cholenamide (DMHCA), that also increased ABCA1 expression in foamy macrophages and even prevented plaque formation in apolipoprotein E-deficient mice (animals with unbalanced cholesterol metabolism in macrophages prone to the formation of inflammatory atherosclerotic plaques) [119-121], may have a beneficial role. Additionally, the PPAR $\gamma$ signaling pathway modulates the activation of $\operatorname{LXR} \alpha$, so that its regulation can indirectly interfere with cholesterol efflux pathways [122]. In fact, studies from Chinetti and colleagues revealed that the treatment of both primary human monocyte-derived macrophages and macrophage-derived foam cells with PPAR- $\alpha / \gamma$ activators-Wy14643 or rosiglitazone and troglitazone-upregulated ABCA1 mRNA levels again interfere with the cholesterol efflux. In the same study, treatment with such PPAR agonists similarly decreased lipid accumulation in monocyte-derived macrophages previously treated with AcLDL, to facilitate cholesteryl-ester accumulation [123].

Other studies approached the histone deacetylase (HDAC) inhibitors for their considerable role in the regulation of NPC1 and 2 gene expression. In vitro studies using NPC1 mutant fibroblasts (with accumulated unesterified cholesterol) treated with LBH589 and Vorinostat, both HDAC inhibitors, increased the expression of NPC1 gene and restored cholesterol homeostasis [124,125]. Even more interesting, fingolimod (FTY720), approved for clinical treatment of MS, is also a HDAC inhibitor. From the Newton et al. study, FTY720-treated mice showed augmented expression of NPC1 and 2 in the hippocampus, cerebellum, and liver, which correlated with decreased liver cholesterol levels after treatment. In the same study, human NPC1 mutant fibroblasts incubated with FTY720 not only increased mRNA expression of NPC membrane proteins but markedly upregulated ABCAA1 membrane lipid transporter, which in turn decreased cholesterol accumulation within mutant cells [126]. Concordantly, FTY720 reduced total cholesterol content in induced-foamy human primary macrophages [127]. Such dual role of FTY720 as immunomodulatory and mediator of intracellular cholesterol trafficking likely undergird its observed beneficial role over remyelination after ex vivo demyelination [128] and microglial activation in MS focal inflammatory lesions [129].

Some of the discussed molecules (resumed in Table 1) require further testing using MS-disease models. However, based on their successful results in restoring lipid metabolism and imbalance, they present a good therapeutic opportunity alone or in a combined manner with phagocytose-enhancing drugs, to overcome remyelination impairment and, therefore, MS progressive disability.

Table 1. List of possible drugs to modulate microglia towards a regenerative phenotype in multiple sclerosis.

\begin{tabular}{|c|c|c|}
\hline \multicolumn{3}{|c|}{ Modulators of Microglial Phagocytic Phenotype } \\
\hline Drug & Mechanism & Reference \\
\hline $\begin{array}{l}\text { Docosahexaenoic acid and } \\
\text { Eicosapentaenoic acid }\end{array}$ & Enhance myelin phagocytosis by microglia & [87] \\
\hline Endocannabinoid 2-AG & $\begin{array}{l}\text { Upregulates the expression levels of phagocytosis associated genes } \\
\text { and promotes microglial myelin uptake }\end{array}$ & [92] \\
\hline Pseudoginsenoside-F11 & Accelerates CR3-dependent myelin phagocytosis by microglial cells & [93] \\
\hline rHIgM22 & $\begin{array}{l}\text { Binds to myelin debris and facilitates their internalization by } \\
\text { microglia }\end{array}$ & [88] \\
\hline Ursolic acid * & $\begin{array}{l}\text { Agonist of PPAR } \gamma \text { signaling, which upregulates the expression of } \\
\text { CD36 receptor, involved in the internalization of } A \beta \text { and lipids }\end{array}$ & [97] \\
\hline Galantamine * & Favors microglial $A \beta$ internalization & [99] \\
\hline
\end{tabular}


Table 1. Cont.

\begin{tabular}{|c|c|c|}
\hline \multicolumn{3}{|c|}{ Modulators of Microglial Lipid Metabolism } \\
\hline Drug & Mechanism & Reference \\
\hline LBH589 \# and Vorinostat \# & $\begin{array}{l}\text { Both HDAC inhibitors that increase NPC expression in fibroblasts, } \\
\text { promoting the release of cholesterol from lysosomes }\end{array}$ & {$[124,125]$} \\
\hline FTY720 & $\begin{array}{l}\text { HDAC inhibitor that also promotes lipid efflux from human } \\
\text { primary macrophage through the overexpression of both NPC } \\
\text { proteins and ABC transporters }\end{array}$ & {$[126,127]$} \\
\hline $\begin{array}{l}\text { DMHCA, GW3965, Wy14643, } \\
\text { Rosiglitazone and Troglitazone }\end{array}$ & $\begin{array}{l}\text { Activators of } \mathrm{LXR} / \mathrm{RXR} \text { heterodimeric transcription factor which } \\
\text { upregulates } \mathrm{ABC} \text { transporters thus also promoting cholesterol/lipid } \\
\text { exit from macrophages }\end{array}$ & [118-123] \\
\hline \multicolumn{3}{|c|}{$\begin{array}{l}\text { * Both Ursolic acid and Galantamine affect cell phagocytosis, for what we highlight them as good candidates to } \\
\text { modulate myelin phagocytosis. }{ }^{\#} \text { The effect of LBH589 and Vorinostat on the expression of NPC proteins in microglia } \\
\text { is unknown. Further studies are needed to evaluate the potential of these molecules on microglial lipid metabolism. } \\
\text { CR3: Complement receptor 3; PPAR: Peroxisome proliferator-activated receptor; A } \beta \text { : Amyloid- } \beta \text {; HDAC: Histone } \\
\text { deacetylase; NPC: Niemann-Pick type disease C; ABC: ATP-binding cassette; LXR: liver X receptor; RXR: Retinoid } \\
\text { X receptor. }\end{array}$} \\
\hline
\end{tabular}

\subsubsection{Phagocytosis and Cognitive Impairment}

The above proposed phagocytose-mediated therapeutic approaches to counteract the MS disease burden can also raise new challenges. Whereas the process of myelin clearance contributes to a less harmful environment within demyelinated plaques, recent studies have strongly correlated microglial phagocytosis with cognitive impairment in MS, for what there is also the loss of treatment perspectives.

In addition to the well visible motor disability of MS patients, cognitive impairment is increasingly recognized as one of the primary features of MS (affecting around $40-60 \%$ of patients). This "invisible" disability that is associated with cortical lesions and atrophy over multiple brain regions may have an early onset, significantly affecting the patient's social interactions, ability to work, and quality of life [130,131]. Studies from Di Filippo and colleagues associate inflammatory responses and its subsequent anomalous release of inflammatory mediators (as in MS) with disruption of glia-neuron crosstalk [131]. Cytokines, acting as neuromodulators, impair synaptic transmission, long term potentiation maintenance, and synaptic plasticity, thus interfering with cognitive functions [132]. Particularly, elevated expression and release of TNF- $\alpha$ were observed to interfere with spontaneous excitatory postsynaptic currents and excessive glutamatergic release [133], ultimately associated with increased neurotoxicity contextual learning-memory impairment in EAE-induced mice $[134,135]$. On the other hand, demyelination potentiates axonal vulnerability to inflammatory damage, thus naturally contributing to neuronal loss and impaired synaptic communications. Particularly vulnerable is the hippocampus, the central region responsible for the maintenance and retrieval of memory where demyelination can be detected on more than $60 \%$ of postmortem MS hippocampi [136,137]. Studies from Dutta et al. also demonstrate that loss of myelin within hippocampal areas were associated with reduced expression of neuronal proteins involved in synaptic integrity, axonal transport, and glutamate homeostasis. This led to a decrease in synaptic density that is in line with a previous imaging study, using magnetic resonance imaging (MRI), correlating altered hippocampal measure and atrophy with memory dysfunction in MS patients [138,139].

However, recent studies using high-resolution confocal microscopy also revealed an extensive synaptic loss in the MS cortex, independent from demyelination and axonal degeneration, strongly implying microglial involvement in synaptic loss and cognitive dysfunction [140]. Indeed, activated microglia were associated with disturbances in glutamate uptake inducing neuronal and synaptic damage in cortical lesions [141] and early memory impairment in EAE mice [142]. Moreover, as described earlier, microglial phagocytosis mediates synaptic refinement during brain development, a process that reactivates in aged-related and neurodegenerative disorders such as AD [143]. Likewise, the microglial-mediated synaptic loss may eventually be involved in MS-associated cognitive impairment. Not only there is an enhanced expression of complement components, namely $\mathrm{C} 1 \mathrm{q}$ 
and C3, over neuroinflammation [144] but also the "don't eat me" signaling protein CD47 that also protects synapses from excessive phagocytosis is found downregulated in chronic MS lesions [114,145]. Consistent with this finding, studies from Michailidou et al. found complement proteins colocalizing with synaptophysin, either in neuronal synapses or inside activated microglia, within both demyelinated and myelinated MS hippocampi [146]. Concordantly, C3-knockout in mice inhibited synapse removal and protected hippocampal neuronal loss during normal aging, accompanied by increased learning and spatial memory when compared to age-matched WT mice [147]. Further relevant, blockage of C3 also preserved synapse density, protected hippocampal synaptic degeneration, and improved cognitive functions on a mouse model of AD [148].

Despite these advantages, the association of microglial role with the MS-characteristic cognitive dysfunction carries future studies and analysis. However, the dual role of complement signaling pathway both in the opsonization of myelin debris and tagging of synapses raises challenging questions: (1) If, by modulating debris phagocytosis and promoting myelin recovery, we will in fact be potentiating a secondary loss of synapses and long-term cognitive impairment; (2) whether it will be possible to modulate phagocytosis independently of the complement system to increase myelin clearing while avoiding extreme synaptic pruning. Thus, the in-depth study of the regulation of synapses phagocytosis while the formation of MS lesions becomes demanding so that we can invest in possible safe therapies targeting myelin clearance without promoting additional neuronal dysfunction and synaptic loss.

\section{Conclusions}

For long, microglia have been the subject of much research in MS regarding their dynamic functions and dual inflammatory role over disease progression. Whereas as pro-inflammatory cells they contribute to disease burden, in an anti-inflammatory and regenerative state they are essential for disease recovery. Based on such unbalanced phenotypic dualities which underlie MS pathology, successful anti-inflammatory therapies have been focused on targeting the microglial immune role, while favoring at the same time, the switch towards the most beneficial phenotype preserving their regenerative functions. On the contrary, therapeutics regarding the microglial main function of phagocytosis have been less explored. In this review, we summarize the contribution of phagocytic process to early development, however focusing on its functional consequences over MS disease progression, not only in myelin removal from demyelinated lesions, but also as a modulator of microglial inflammatory responses. Therefore, the microglial phagocytic dysfunction results in severe motor and cognitive MS-associated symptoms so that we highlight newly phagocytic-directed approaches, which we discuss that in combination with anti-inflammatory molecules may achieve promising results regarding MS therapeutics. Importantly, the challenge will be to find a balance between complement-mediated myelin clearance and synaptic removal in order to find successful phagocytosis-targeted drugs and their optimization towards clinical applications to ameliorate disease pathogenesis or even promote the full patient's recovery.

Funding: This work was supported by the following grants: Grant for Multiple Sclerosis Innovation-Merck Serono to AF, and, in part, by UID/DTP/04138/2019-from Fundação para a Ciência e Tecnologia (FCT), Portugal to iMed.ULisboa.

Conflicts of Interest: The authors declare no conflict of interest. The funders had no role in the writing of the manuscript.

\section{References}

1. WHO. Atlas Multiple Sclerosis resources. In The World 2008; WHO Press: Geneva, Switzerland, 2008; Volume 56.

2. Bogie, J.F.; Stinissen, P.; Hendriks, J.J. Macrophage subsets and microglia in multiple sclerosis. Acta Neuropathol. 2014, 128, 191-213. [CrossRef] [PubMed]

3. Uleng Bahrun, C.W. Immunology of multiple sclerosis. Indones. J. Clin. Pathol. Med Lab. 2018, 24, 191-195. [CrossRef] 
4. Yamout, B.I.; Alroughani, R. Multiple sclerosis. Semin. Neurol. 2018, 38, 212-225. [CrossRef]

5. Weil, M.T.; Mobius, W.; Winkler, A.; Ruhwedel, T.; Wrzos, C.; Romanelli, E.; Bennett, J.L.; Enz, L.; Goebels, N.; Nave, K.A.; et al. Loss of myelin basic protein function triggers myelin breakdown in models of demyelinating diseases. Cell Rep. 2016, 16, 314-322. [CrossRef] [PubMed]

6. Grigoriadis, N.; van Pesch, V.; Paradig, M.S.G. A basic overview of multiple sclerosis immunopathology. Eur. J. Neurol. 2015, 22 (Suppl. 2), 3-13. [CrossRef] [PubMed]

7. Ransohoff, R.M. Animal models of multiple sclerosis: The good, the bad and the bottom line. Nat. Neurosci. 2012, 15, 1074-1077. [CrossRef]

8. Compston, A.; Coles, A. Multiple sclerosis. Lancet 2008, 372, 1502-1517. [CrossRef]

9. Hojati, Z.; Kay, M.; Dehghanian, F. Mechanism of action of interferon beta in treatment of multiple sclerosis. In Multiple Sclerosis; Academic Press: Cambridge, MA, USA, 2016; pp. 365-392. [CrossRef]

10. Tselis, A.; Khan, O.; Lisak, R.P. Glatiramer acetate in the treatment of multiple sclerosis. Neuropsychiatr. Dis. Treat. 2007, 3, 259-267. [CrossRef]

11. Racke, M.K.; Lovett-Racke, A.E.; Karandikar, N.J. The mechanism of action of glatiramer acetate treatment in multiple sclerosis. Neurology 2010, 74, S25-S30. [CrossRef]

12. Ayzenberg, I.; Hoepner, R.; Kleiter, I. Fingolimod for multiple sclerosis and emerging indications: Appropriate patient selection, safety precautions, and special considerations. Ther. Clin. Risk Manag. 2016, 12, 261-272. [CrossRef]

13. Polman, C.H.; O'Connor, P.W.; Havrdova, E.; Hutchinson, M.; Kappos, L.; Miller, D.H.; Theodore Phillips, J.; Lublin, F.D.; Giovannoni, G.; Wajgt, A.; et al. A randomized, placebo-controlled trial of natalizumab for relapsing multiple sclerosis. N. Engl. J. Med. 2006, 354, 899-910. [CrossRef]

14. Brandstadter, R.; Katz Sand, I. The use of natalizumab for multiple sclerosis. Neuropsychiatr. Dis. Treat. 2017, 13, 1691-1702. [CrossRef]

15. Brown, J.W.; Coles, A.J. Alemtuzumab: Evidence for its potential in relapsing-remitting multiple sclerosis. Drug Des. Dev. Ther. 2013, 7, 131-138. [CrossRef] [PubMed]

16. Mulero, P.; Midaglia, L.; Montalban, X. Ocrelizumab: A new milestone in multiple sclerosis therapy. Ther. Adv. Neurol. Disord. 2018, 11, 1756286418773025. [CrossRef]

17. Chari, D.M. Remyelination in multiple sclerosis. Int. Rev. Neurobiol. 2007, 79, 589-620. [CrossRef] [PubMed]

18. Zawadzka, M.; Rivers, L.E.; Fancy, S.P.; Zhao, C.; Tripathi, R.; Jamen, F.; Young, K.; Goncharevich, A.; Pohl, H.; Rizzi, M.; et al. CNS-resident glial progenitor/stem cells produce Schwann cells as well as oligodendrocytes during repair of CNS demyelination. Cell Stem Cell 2010, 6, 578-590. [CrossRef]

19. Moyon, S.; Dubessy, A.L.; Aigrot, M.S.; Trotter, M.; Huang, J.K.; Dauphinot, L.; Potier, M.C.; Kerninon, C.; Melik Parsadaniantz, S.; Franklin, R.J.; et al. Demyelination causes adult CNS progenitors to revert to an immature state and express immune cues that support their migration. J. Neurosci. Off. J. Soc. Neurosci. 2015, 35, 4-20. [CrossRef]

20. Boyd, A.; Zhang, H.; Williams, A. Insufficient OPC migration into demyelinated lesions is a cause of poor remyelination in MS and mouse models. Acta Neuropathol. 2013, 125, 841-859. [CrossRef] [PubMed]

21. Franklin, R.J.; Goldman, S.A. Glia disease and repair-remyelination. Cold Spring Harb. Perspect. Biol. 2015, 7, a020594. [CrossRef] [PubMed]

22. McMurran, C.E.; Jones, C.A.; Fitzgerald, D.C.; Franklin, R.J. CNS Remyelination and the innate immune system. Front. Cell Dev. Biol. 2016, 4, 38. [CrossRef] [PubMed]

23. Green, A.J.; Gelfand, J.M.; Cree, B.A.; Bevan, C.; Boscardin, W.J.; Mei, F.; Inman, J.; Arnow, S.; Devereux, M.; Abounasr, A.; et al. Clemastine fumarate as a remyelinating therapy for multiple sclerosis (ReBUILD): A randomised, controlled, double-blind, crossover trial. Lancet 2017, 390, 2481-2489. [CrossRef]

24. Cardona, A.E.; Huang, D.; Sasse, M.E.; Ransohoff, R.M. Isolation of murine microglial cells for RNA analysis or flow cytometry. Nat. Protoc. 2006, 1, 1947-1951. [CrossRef]

25. Perry, V.H.; Nicoll, J.A.; Holmes, C. Microglia in neurodegenerative disease. Nat. Rev. Neurol. 2010, 6, 193-201. [CrossRef] [PubMed]

26. Soulet, D.; Rivest, S. Bone-marrow-derived microglia: Myth or reality? Curr. Opin. Pharmacol. 2008, 8, 508-518. [CrossRef]

27. Ling, E.; Penney, D.; Leblond, C. Use of carbon labeling to demonstrate the role of blood monocytes as precursors of the 'Ameboid Cells' present in the corpus callosum of postnatal rats. J. Comp. Neurol. 1980, 193, 631-657. [CrossRef] [PubMed] 
28. Nimmerjahn, A.; Kirchhoff, F.; Helmchen, F. Resting microglial cells are highly dynamic surveillants of brain parenchyma in vivo. Science 2005, 308, 1314-1318. [CrossRef]

29. von Bernhardi, R.; Heredia, F.; Salgado, N.; Munoz, P. Microglia function in the normal brain. Adv. Exp. Med. Biol. 2016, 949, 67-92. [CrossRef]

30. Hanisch, U.K.; Kettenmann, H. Microglia: Active sensor and versatile effector cells in the normal and pathologic brain. Nat. Neurosci. 2007, 10, 1387-1394. [CrossRef]

31. Parkhurst, C.N.; Yang, G.; Ninan, I.; Savas, J.N.; Yates, J.R., 3rd; Lafaille, J.J.; Hempstead, B.L.; Littman, D.R.; Gan, W.B. Microglia promote learning-dependent synapse formation through brain-derived neurotrophic factor. Cell 2013, 155, 1596-1609. [CrossRef]

32. Ji, K.; Akgul, G.; Wollmuth, L.P.; Tsirka, S.E. Microglia actively regulate the number of functional synapses. PLoS ONE 2013, 8, e56293. [CrossRef]

33. Ueno, M.; Fujita, Y.; Tanaka, T.; Nakamura, Y.; Kikuta, J.; Ishii, M.; Yamashita, T. Layer V cortical neurons require microglial support for survival during postnatal development. Nat. Neurosci. 2013, 16, 543-551. [CrossRef] [PubMed]

34. Nelson, L.H.; Warden, S.; Lenz, K.M. Sex differences in microglial phagocytosis in the neonatal hippocampus. Brain Behav. Immun. 2017, 64, 11-22. [CrossRef] [PubMed]

35. VanRyzin, J.W.; Marquardt, A.E.; Argue, K.J.; Vecchiarelli, H.A.; Ashton, S.E.; Arambula, S.E.; Hill, M.N.; McCarthy, M.M. Microglial phagocytosis of newborn cells is induced by endocannabinoids and sculpts sex differences in juvenile rat social play. Neuron 2019, 102, 435-449.e6. [CrossRef] [PubMed]

36. Nicholas, R.S.; Wing, M.G.; Compston, A. Nonactivated microglia promote oligodendrocyte precursor survival and maturation through the transcription factor NF-kappa B. Eur. J. Neurosci. 2001, 13, 959-967. [CrossRef]

37. Pasquini, L.A.; Millet, V.; Hoyos, H.C.; Giannoni, J.P.; Croci, D.O.; Marder, M.; Liu, F.T.; Rabinovich, G.A.; Pasquini, J.M. Galectin-3 drives oligodendrocyte differentiation to control myelin integrity and function. Cell Death Differ. 2011, 18, 1746-1756. [CrossRef]

38. Hoyos, H.C.; Rinaldi, M.; Mendez-Huergo, S.P.; Marder, M.; Rabinovich, G.A.; Pasquini, J.M.; Pasquini, L.A. Galectin-3 controls the response of microglial cells to limit cuprizone-induced demyelination. Neurobiol. Dis. 2014, 62, 441-455. [CrossRef]

39. Orr, A.G.; Orr, A.L.; Li, X.J.; Gross, R.E.; Traynelis, S.F. Adenosine A(2A) receptor mediates microglial process retraction. Nat. Neurosci. 2009, 12,872-878. [CrossRef]

40. Stence, N.; Waite, M.; Dailey, M.E. Dynamics of microglial activation: A confocal time-lapse analysis in hippocampal slices. Glia 2001, 33, 256-266. [CrossRef]

41. Lynch, M.A. The multifaceted profile of activated microglia. Mol. Neurobiol. 2009, 40, 139-156. [CrossRef]

42. Hendrickx, D.A.E.; van Eden, C.G.; Schuurman, K.G.; Hamann, J.; Huitinga, I. Staining of HLA-DR, Iba1 and CD68 in human microglia reveals partially overlapping expression depending on cellular morphology and pathology. J. Neuroimmunol. 2017, 309, 12-22. [CrossRef]

43. Gomes-Leal, W. Microglial physiopathology: How to explain the dual role of microglia after acute neural disorders? Brain Behav. 2012, 2, 345-356. [CrossRef] [PubMed]

44. Miron, V.E.; Boyd, A.; Zhao, J.W.; Yuen, T.J.; Ruckh, J.M.; Shadrach, J.L.; van Wijngaarden, P.; Wagers, A.J.; Williams, A.; Franklin, R.J.M.; et al. M2 microglia and macrophages drive oligodendrocyte differentiation during CNS remyelination. Nat. Neurosci. 2013, 16, 1211-1218. [CrossRef] [PubMed]

45. Prinz, M.; Jung, S.; Priller, J. Microglia biology: One century of evolving concepts. Cell 2019, 179, $292-311$. [CrossRef] [PubMed]

46. Haider, L.; Fischer, M.T.; Frischer, J.M.; Bauer, J.; Hoftberger, R.; Botond, G.; Esterbauer, H.; Binder, C.J.; Witztum, J.L.; Lassmann, H. Oxidative damage in multiple sclerosis lesions. Brain J. Neurol. 2011, 134, 1914-1924. [CrossRef]

47. Jiang, Z.; Jiang, J.X.; Zhang, G.X. Macrophages: A double-edged sword in experimental autoimmune encephalomyelitis. Immunol. Lett. 2014, 160, 17-22. [CrossRef]

48. Abourbeh, G.; Theze, B.; Maroy, R.; Dubois, A.; Brulon, V.; Fontyn, Y.; Dolle, F.; Tavitian, B.; Boisgard, R. Imaging microglial/macrophage activation in spinal cords of experimental autoimmune encephalomyelitis rats by positron emission tomography using the mitochondrial $18 \mathrm{kDa}$ translocator protein radioligand [(1)(8)F]DPA-714. J. Neurosci. Off. J. Soc. Neurosci. 2012, 32, 5728-5736. [CrossRef] 
49. Zhang, B.; Wei, Y.Z.; Wang, G.Q.; Li, D.D.; Shi, J.S.; Zhang, F. Targeting MAPK pathways by naringenin modulates microglia M1/M2 polarization in lipopolysaccharide-stimulated cultures. Front. Cell. Neurosci. 2018, 12, 531. [CrossRef]

50. Wang, J.; Qi, Y.; Niu, X.; Tang, H.; Meydani, S.N.; Wu, D. Dietary naringenin supplementation attenuates experimental autoimmune encephalomyelitis by modulating autoimmune inflammatory responses in mice. J. Nutr. Biochem. 2018, 54, 130-139. [CrossRef]

51. Djedovic, N.; Stanisavljevic, S.; Jevtic, B.; Momcilovic, M.; Lavrnja, I.; Miljkovic, D. Anti-encephalitogenic effects of ethyl pyruvate are reflected in the central nervous system and the gut. Biomed. Pharmacother. 2017, 96, 78-85. [CrossRef]

52. Veremeyko, T.; Yung, A.W.Y.; Dukhinova, M.; Kuznetsova, I.S.; Pomytkin, I.; Lyundup, A.; Strekalova, T.; Barteneva, N.S.; Ponomarev, E.D. Cyclic AMP pathway suppress autoimmune neuroinflammation by inhibiting functions of Encephalitogenic CD4 T cells and enhancing M2 macrophage polarization at the site of inflammation. Front. Immunol. 2018, 9, 50. [CrossRef]

53. Fan, C.; Long, R.; You, Y.; Wang, J.; Yang, X.; Huang, S.; Sheng, Y.; Peng, X.; Liu, H.; Wang, Z.; et al. A novel PADRE-Kv1.3 vaccine effectively induces therapeutic antibodies and ameliorates experimental autoimmune encephalomyelitis in rats. Clin. Immunol. 2018, 193, 98-109. [CrossRef] [PubMed]

54. Sun, D.; Yu, Z.; Fang, X.; Liu, M.; Pu, Y.; Shao, Q.; Wang, D.; Zhao, X.; Huang, A.; Xiang, Z.; et al. LncRNA GAS5 inhibits microglial M2 polarization and exacerbates demyelination. EMBO Rep. 2017, 18, 1801-1816. [CrossRef] [PubMed]

55. Wang, J.; Wang, J.; Wang, J.; Yang, B.; Weng, Q.; He, Q. Targeting microglia and macrophages: A potential treatment strategy for multiple sclerosis. Front. Pharmacol. 2019, 10, 286. [CrossRef] [PubMed]

56. Du, L.; Zhang, Y.; Chen, Y.; Zhu, J.; Yang, Y.; Zhang, H.L. Role of microglia in neurological disorders and their potentials as a therapeutic target. Mol. Neurobiol. 2017, 54, 7567-7584. [CrossRef]

57. Neumann, H.; Kotter, M.R.; Franklin, R.J. Debris clearance by microglia: An essential link between degeneration and regeneration. Brain J. Neurol. 2009, 132, 288-295. [CrossRef]

58. Lampron, A.; Larochelle, A.; Laflamme, N.; Prefontaine, P.; Plante, M.M.; Sanchez, M.G.; Yong, V.W.; Stys, P.K.; Tremblay, M.E.; Rivest, S. Inefficient clearance of myelin debris by microglia impairs remyelinating processes. J. Exp. Med. 2015, 212, 481-495. [CrossRef]

59. Galloway, D.A.; Phillips, A.E.M.; Owen, D.R.J.; Moore, C.S. Phagocytosis in the brain: Homeostasis and disease. Front. Immunol. 2019, 10, 790. [CrossRef]

60. Tremblay, M.E.; Lowery, R.L.; Majewska, A.K. Microglial interactions with synapses are modulated by visual experience. PLoS Biol. 2010, 8, e1000527. [CrossRef]

61. Paolicelli, R.C.; Bolasco, G.; Francesca, P.; Laura, M.; Maria, S.; Patrizia, P.; Maurizio, G.; Ferreira, T.A.; Guiducci, E.; Dumas, L.; et al. Synaptic pruning by microglia is necessary for normal brain development. Science 2011, 333, 1456-1458. [CrossRef]

62. Dissing-Olesen, L.; LeDue, J.M.; Rungta, R.L.; Hefendehl, J.K.; Choi, H.B.; MacVicar, B.A. Activation of neuronal NMDA receptors triggers transient ATP-mediated microglial process outgrowth. J. Neurosci. Off. J. Soc. Neurosci. 2014, 34, 10511-10527. [CrossRef]

63. Sipe, G.O.; Lowery, R.L.; Tremblay, M.E.; Kelly, E.A.; Lamantia, C.E.; Majewska, A.K. Microglial P2Y12 is necessary for synaptic plasticity in mouse visual cortex. Nat. Commun. 2016, 7, 10905. [CrossRef] [PubMed]

64. Schafer, D.P.; Stevens, B. Phagocytic glial cells: Sculpting synaptic circuits in the developing nervous system. Curr. Opin. Neurobiol. 2013, 23, 1034-1040. [CrossRef] [PubMed]

65. Schafer, D.P.; Lehrman, E.K.; Kautzman, A.G.; Koyama, R.; Mardinly, A.R.; Yamasaki, R.; Ransohoff, R.M.; Greenberg, M.E.; Barres, B.A.; Stevens, B. Microglia sculpt postnatal neural circuits in an activity and complement-dependent manner. Neuron 2012, 74, 691-705. [CrossRef] [PubMed]

66. Bernardinelli, Y.; Nikonenko, I.; Muller, D. Structural plasticity: Mechanisms and contribution to developmental psychiatric disorders. Front. Neuroanat. 2014, 8, 123. [CrossRef] [PubMed]

67. Haberl, M.; Zerbi, V.; Veltien, A.; Ginger, M.; Heerschap, A.; Frick, A. Structural-functional connectivity deficits of neocortical circuits in the Fmr1-/y mouse model of autism. Funct. Neuroimaging 2015, 1, e1500775. [CrossRef]

68. Schreiner, M.J.; Karlsgodt, K.H.; Uddin, L.Q.; Chow, C.; Congdon, E.; Jalbrzikowski, M.; Bearden, C.E. Default mode network connectivity and reciprocal social behavior in 22q11.2 deletion syndrome. Soc. Cognit. Affect. Neurosci. 2014, 9, 1261-1267. [CrossRef] 
69. Stevens, B.; Allen, N.J.; Vazquez, L.E.; Howell, G.R.; Christopherson, K.S.; Nouri, N.; Micheva, K.D.; Mehalow, A.K.; Huberman, A.D.; Stafford, B.; et al. The classical complement cascade mediates CNS synapse elimination. Cell 2007, 131, 1164-1178. [CrossRef]

70. Anderson, S.R.; Zhang, J.; Steele, M.R.; Romero, C.O.; Kautzman, A.G.; Schafer, D.P.; Vetter, M.L. Complement targets newborn retinal ganglion cells for phagocytic elimination by microglia. J. Neurosci. Off. J. Soc. Neurosci. 2019, 39, 2025-2040. [CrossRef]

71. Harrison, J.K.; Jiang, Y.; Chen, S.; Xia, Y.; Maciejewski, D.; Mcnamara, R.K.; Streiti, W.J.; Salafranca, M.N.; Adhikari, S.; Thompson, D.A.; et al. Role for neuronally derived fractalkine in mediating interactions between neurons and CX3CR1-expressing microglia. Neurobiology 1998, 95, 10896-10901. [CrossRef]

72. Filipello, F.; Morini, R.; Corradini, I.; Zerbi, V.; Canzi, A.; Michalski, B.; Erreni, M.; Markicevic, M.; Starvaggi-Cucuzza, C.; Otero, K.; et al. The microglial innate immune receptor TREM2 is required for synapse elimination and normal brain connectivity. Immunity 2018, 48, 979-991.e8. [CrossRef]

73. Casano, A.M.; Albert, M.; Peri, F. Developmental apoptosis mediates entry and positioning of microglia in the Zebrafish Brain. Cell Rep. 2016, 16, 897-906. [CrossRef] [PubMed]

74. Blume, Z.I.; Lambert, J.M.; Lovel, A.G.; Mitchell, D.M. Microglia in the developing retina couple phagocytosis with the progression of apoptosis via P2RY12 signaling. Dev. Dyn. Off. Publ. Am. Assoc. Anat. 2020, 249, 723-740. [CrossRef] [PubMed]

75. Fourgeaud, L.; Traves, P.G.; Tufail, Y.; Leal-Bailey, H.; Lew, E.D.; Burrola, P.G.; Callaway, P.; Zagorska, A.; Rothlin, C.V.; Nimmerjahn, A.; et al. TAM receptors regulate multiple features of microglial physiology. Nature 2016, 532, 240-244. [CrossRef] [PubMed]

76. Diaz-Aparicio, I.; Sierra, A. C1q is related to microglial phagocytosis in the hippocampus in physiological conditions. Matters 2019, 5, e201904000013. [CrossRef]

77. Perez-Pouchoulen, M.; Yu, S.J.; Roby, C.R.; Bonsavage, N.; McCarthy, M.M. Regulatory control of microglial phagocytosis by estradiol and prostaglandin E2 in the developing rat cerebellum. Cerebellum 2019, 18, 882-895. [CrossRef]

78. Chen, M.S.; Huber, A.B.; van der Haar, M.E.; Frank, M.; Schnell, L.; Spillmann, A.A.; Christ, F.; Schwab, M.E. Nogo-A is a myelin-associated neurite outgrowth inhibitor and an antigen for monoclonal antibody IN-1. Nature 2000, 403, 434-439. [CrossRef]

79. Plemel, J.R.; Manesh, S.B.; Sparling, J.S.; Tetzlaff, W. Myelin inhibits oligodendroglial maturation and regulates oligodendrocytic transcription factor expression. Glia 2013, 61, 1471-1487. [CrossRef]

80. McKerracher, L.; David, S.; Jackson, D.L.; Kottis, V.; Dunn, R.J.; Braun, P.E. Identification of myelin-associated glycoprotein as a major myelin-derived inhibitor of neurite growth. Neuron 1994, 13, 805-811. [CrossRef]

81. Brück, W.; Friede, R.L. Anti-macrophage CR3 antibody blocks myelin phagocytosis by macrophages in vitro. Acta Neuropathol. 1990, 80, 415-418. [CrossRef]

82. Reichert, F.; Rotshenker, S. Complement-receptor-3 and scavenger-receptor-AI/II mediated myelin phagocytosis in microglia and macrophages. Neurobiol. Dis. 2003, 12, 65-72. [CrossRef]

83. Poliani, P.L.; Wang, Y.; Fontana, E.; Robinette, M.L.; Yamanishi, Y.; Gilfillan, S.; Colonna, M. TREM2 sustains microglial expansion during aging and response to demyelination. J. Clin. Investig. 2015, 125, 2161-2170. [CrossRef] [PubMed]

84. Piccio, L.; Buonsanti, C.; Mariani, M.; Cella, M.; Gilfillan, S.; Cross, A.H.; Colonna, M.; Panina-Bordignon, P. Blockade of TREM-2 exacerbates experimental autoimmune encephalomyelitis. Eur. J. Immunol. 2007, 37, 1290-1301. [CrossRef] [PubMed]

85. Healy, L.M.; Perron, G.; Won, S.Y.; Michell-Robinson, M.A.; Rezk, A.; Ludwin, S.K.; Moore, C.S.; Hall, J.A.; Bar-Or, A.; Antel, J.P. MerTK is a functional regulator of myelin phagocytosis by human myeloid cells. J. Immunol. 2016, 196, 3375-3384. [CrossRef] [PubMed]

86. Healy, L.M.; Jang, J.H.; Won, S.Y.; Lin, Y.H.; Touil, H.; Aljarallah, S.; Bar-Or, A.; Antel, J.P. MerTK-mediated regulation of myelin phagocytosis by macrophages generated from patients with MS. Neurol. Neuroimmunol. Neuroinflamm. 2017, 4, e402. [CrossRef]

87. Chen, S.; Zhang, H.; Pu, H.; Wang, G.; Li, W.; Leak, R.K.; Chen, J.; Liou, A.K.; Hu, X. n-3 PUFA supplementation benefits microglial responses to myelin pathology. Sci. Rep. 2014, 4, 7458. [CrossRef]

88. Zorina, Y.; Stricker, J.; Caggiano, A.O.; Button, D.C. Human IgM antibody rHIgM22 promotes phagocytic clearance of myelin debris by microglia. Sci. Rep. 2018, 8, 9392. [CrossRef] 
89. Warrington, A.E.; Bieber, A.J.; Ciric, B.; Pease, L.; Van Keulen, V.P.; Rodriguez, M. A recombinant human IgM promotes myelin repair after a single, very low dose. J. Neurosci. Res. 2007, 85, 967-976. [CrossRef]

90. Mullin, A.P.; Cui, C.; Wang, Y.; Wang, J.; Troy, E.; Caggiano, A.O.; Parry, T.J.; Colburn, R.W.; Pavlopoulos, E. rHIgM22 enhances remyelination in the brain of the cuprizone mouse model of demyelination. Neurobiol. Dis. 2017, 105, 142-155. [CrossRef]

91. Cui, C.; Wang, J.; Mullin, A.P.; Caggiano, A.O.; Parry, T.J.; Colburn, R.W.; Pavlopoulos, E. The antibody rHIgM22 facilitates hippocampal remyelination and ameliorates memory deficits in the cuprizone mouse model of demyelination. Brain Res. 2018, 1694, 73-86. [CrossRef]

92. Mecha, M.; Yanguas-Casas, N.; Feliu, A.; Mestre, L.; Carrillo-Salinas, F.; Azcoitia, I.; Yong, V.W.; Guaza, C. The endocannabinoid 2-AG enhances spontaneous remyelination by targeting microglia. Brain Behav. Immun. 2019, 77, 110-126. [CrossRef]

93. Liu, Y.; Wu, C.; Hou, Z.; Fu, X.; Yuan, L.; Sun, S.; Zhang, H.; Yang, D.; Yao, X.; Yang, J. Pseudoginsenoside-F11 accelerates microglial phagocytosis of myelin debris and attenuates cerebral ischemic injury through complement receptor 3. Neuroscience 2020, 426, 33-49. [CrossRef] [PubMed]

94. Bogie, J.F.J.; Jorissen, W.; Mailleux, J.; Nijland, P.G.; Zelcer, N.; Vanmierlo, T.; Van Horssen, J.; Stinissen, P.; Hellings, N.; Hendriks, J. Myelin alters the inflammatory phenotype of macrophages by activating PPARs. Acta Neuropathol. Commun. 2013, 1, 43. [CrossRef]

95. Kopper, T.J.; Gensel, J.C. Myelin as an inflammatory mediator: Myelin interactions with complement, macrophages, and microglia in spinal cord injury. J. Neurosci. Res. 2018, 96, 969-977. [CrossRef] [PubMed]

96. Yamanaka, M.; Ishikawa, T.; Griep, A.; Axt, D.; Kummer, M.P.; Heneka, M.T. PPARgamma/RXRalpha-induced and CD36-mediated microglial amyloid-beta phagocytosis results in cognitive improvement in amyloid precursor protein/presenilin 1 mice. J. Neurosci. Off. J. Soc. Neurosci. 2012, 32, 17321-17331. [CrossRef]

97. Yuan Zhang, Y.; Li, X.; Ciric, B.; Curtis, M.; Chen, W.-J.; Rostami, A.; Zhang, G. A dual effect of ursolic acid to the treatment of multiple sclerosis through both immunomodulation and direct remyelination. Proc. Natl. Acad. Sci. USA 2020, 117, 9082-9093. [CrossRef]

98. Olin, J.; Schneider, L. Galantamine for Dementia due to Alzheimer's Disease; Wiley: Hoboken, NJ, USA, 2002.

99. Takata, K.; Kitamura, Y.; Saeki, M.; Terada, M.; Kagitani, S.; Kitamura, R.; Fujikawa, Y.; Maelicke, A.; Tomimoto, H.; Taniguchi, T.; et al. Galantamine-induced amyloid-\{beta\} clearance mediated via stimulation of microglial nicotinic acetylcholine receptors. J. Biol. Chem. 2010, 285, 40180-40191. [CrossRef]

100. Grajchen, E.; Hendriks, J.J.A.; Bogie, J.F.J. The physiology of foamy phagocytes in multiple sclerosis. Acta Neuropathol. Commun. 2018, 6, 124. [CrossRef]

101. Zani, I.A.; Stephen, S.L.; Mughal, N.A.; Russell, D.; Homer-Vanniasinkam, S.; Wheatcroft, S.B.; Ponnambalam, S. Scavenger receptor structure and function in health and disease. Cells 2015, 4, 178-201. [CrossRef]

102. Sun, X.; Wang, X.; Chen, T.; Li, T.; Cao, K.; Lu, A.; Chen, Y.; Sun, D.; Luo, J.; Fan, J.; et al. Myelin activates FAK/Akt/NF-kappaB pathways and provokes CR3-dependent inflammatory response in murine system. PLoS ONE 2010, 5, e9380. [CrossRef]

103. Cantoni, C.; Bollman, B.; Licastro, D.; Xie, M.; Mikesell, R.; Schmidt, R.; Yuede, C.M.; Galimberti, D.; Olivecrona, G.; Klein, R.S.; et al. TREM2 regulates microglial cell activation in response to demyelination in vivo. Acta Neuropathol. 2015, 129, 429-447. [CrossRef]

104. Diemel, L.T.; Jackson, S.J.; Cuzner, M.L. Role for TGF-beta1, FGF-2 and PDGF-AA in a myelination of CNS aggregate cultures enriched with macrophages. J. Neurosci. Res. 2003, 74, 858-867. [CrossRef] [PubMed]

105. McKinnon, R.D.; Piras, G.; Ida, J.A., Jr.; Dubois-Dalcq, M. A role for TGF-beta in oligodendrocyte differentiation. J. Cell. Biol. 1993, 121, 1397-1407. [CrossRef] [PubMed]

106. Bogie, J.F.; Timmermans, S.; Huynh-Thu, V.A.; Irrthum, A.; Smeets, H.J.; Gustafsson, J.A.; Steffensen, K.R.; Mulder, M.; Stinissen, P.; Hellings, N.; et al. Myelin-derived lipids modulate macrophage activity by liver X receptor activation. PLoS ONE 2012, 7, e44998. [CrossRef] [PubMed]

107. Raine, C.S. Multiple sclerosis: The resolving lesion revealed. J. Neuroimmunol. 2017, 304, 2-6. [CrossRef] [PubMed]

108. van Zwam, M.; Samsom, J.N.; Nieuwenhuis, E.E.; Melief, M.J.; Wierenga-Wolf, A.F.; Dijke, I.E.; Talens, S.; van Meurs, M.; Voerman, J.S.; Boven, L.A.; et al. Myelin ingestion alters macrophage antigen-presenting function in vitro and in vivo. J. Leukoc. Biol. 2011, 90, 123-132. [CrossRef] 
109. Loving, B.A.; Bruce, K.D. Lipid and lipoprotein metabolism in microglia. Front. Physiol. 2020, 11, 393. [CrossRef]

110. Remmerie, A.; Scott, C.L. Macrophages and lipid metabolism. Cell Immunol. 2018, 330, 27-42. [CrossRef]

111. Moore, K.J.; Sheedy, F.J.; Fisher, E.A. Macrophages in atherosclerosis: A dynamic balance. Nat. Rev. Immunol. 2013, 13, 709-721. [CrossRef]

112. Marschallinger, J.; Iram, T.; Zardeneta, M.; Lee, S.E.; Lehallier, B.; Haney, M.S.; Pluvinage, J.V.; Mathur, V.; Hahn, O.; Morgens, D.W.; et al. Lipid-droplet-accumulating microglia represent a dysfunctional and proinflammatory state in the aging brain. Nat. Neurosci. 2020, 23, 194-208. [CrossRef]

113. Junker, A.; Krumbholz, M.; Eisele, S.; Mohan, H.; Augstein, F.; Bittner, R.; Lassmann, H.; Wekerle, H.; Hohlfeld, R.; Meinl, E. MicroRNA profiling of multiple sclerosis lesions identifies modulators of the regulatory protein CD47. Brain J. Neurol. 2009, 132, 3342-3352. [CrossRef]

114. Koning, N.; Bo, L.; Hoek, R.M.; Huitinga, I. Downregulation of macrophage inhibitory molecules in multiple sclerosis lesions. Ann. Neurol. 2007, 62, 504-514. [CrossRef] [PubMed]

115. Hendrickx, D.A.; Koning, N.; Schuurman, K.G.; van Strien, M.E.; van Eden, C.G.; Hamann, J.; Huitinga, I. Selective upregulation of scavenger receptors in and around demyelinating areas in multiple sclerosis. J. Neuropathol. Exp. Neurol. 2013, 72, 106-118. [CrossRef] [PubMed]

116. Gitik, M.; Liraz-Zaltsman, S.; Oldenborg, P.A.; Reichert, F.; Rotshenker, S. Myelin down-regulates myelin phagocytosis by microglia and macrophages through interactions between CD47 on myelin and SIRPalpha (signal regulatory protein-alpha) on phagocytes. J. Neuroinflamm. 2011, 8, 24. [CrossRef] [PubMed]

117. Zhao, C.; Dahlman-Wright, K. Liver X receptor in cholesterol metabolism. J. Endocrinol. 2010, 204, $233-240$. [CrossRef] [PubMed]

118. Cantuti-Castelvetri, L.; Fitzner, D.; Bosch-Queralt, M.; Weil, M.-T.; Su, M.; Sen, P.; Ruhwedel, T.; Mitkovski, M.; Trendelenburg, G.; Lütjohann, D.; et al. Defective cholesterol clearance limits remyelination in the aged central nervous system. Science 2018, 359, 684-688. [CrossRef]

119. Kratzer, A.; Buchebner, M.; Pfeifer, T.; Becker, T.M.; Uray, G.; Miyazaki, M.; Miyazaki-Anzai, S.; Ebner, B.; Chandak, P.G.; Kadam, R.S.; et al. Synthetic LXR agonist attenuates plaque formation in apoE-/- mice without inducing liver steatosis and hypertriglyceridemia. J. Lipid Res. 2009, 50, 312-326. [CrossRef]

120. Tangirala, R.K.; Bischoff, E.D.; Joseph, S.B.; Wagner, B.L.; Walczak, R.; Laffitte, B.A.; Daige, C.L.; Thomas, D.; Heyman, R.A.; Mangelsdorf, D.J.; et al. Identification of macrophage liver $\mathrm{X}$ receptors as inhibitors of atherosclerosis. Proc. Natl. Acad. Sci. USA 2002, 99, 11896-11901. [CrossRef]

121. Popko, B.; Chen, Y. Cholesterol crystals impede nerve repair. Science 2018, 359, 635-636.

122. Chawla, A.; Boisvert, W.A.; Lee, C.-H.; Laffitte, B.A.; Barak, Y.; Joseph, S.B.; Liao, D.; Nagy, L.; Edwards, P.A.; Curtiss, L.K.; et al. A PPARg-LXR-ABCA1 pathway in macrophages is involved in cholesterol efflux and atherogenesis. Mol. Cell 2001, 7, 161-171. [CrossRef]

123. Chinetti, G.; Lestavel, S.; Bocher, V.; Remaley, A.T.; Neve, B.; Torra, I.P.; Teissier, E.; Minnich, A.; Jaye, M.; Duverger, N.; et al. PPAR- $\alpha$ and PPAR- $\gamma$ activators induce cholesterol removal from human macrophage foam cells through stimulation of the ABCA1 pathway. Nat. Med. 2001, 7, 53-58. [CrossRef]

124. Pipalia, N.; Cosner, C.C.; Huang, A.; Chatterjee, A.; Bourbon, P.; Farley, N.; Helquist, P.; Wiest, O.; Maxfield, F.R. Histone deacetylase inhibitor treatment dramatically reduces cholesterol accumulation in Niemann-Pick type C1 mutant human fibroblasts. Proc. Natl. Acad. Sci. USA 2011, 108, 5620-5625. [CrossRef] [PubMed]

125. Subramanian, K.; Rauniyar, N.; Lavallee-Adam, M.; Yates, J.R., 3rd; Balch, W.E. Quantitative analysis of the proteome response to the Histone Deacetylase Inhibitor (HDACi) Vorinostat in Niemann-Pick Type C1 disease. Mol. Cell. Proteom. MCP 2017, 16, 1938-1957. [CrossRef] [PubMed]

126. Newton, J.; Hait, N.C.; Maceyka, M.; Colaco, A.; Maczis, M.; Wassif, C.A.; Cougnoux, A.; Porter, F.D.; Milstien, S.; Platt, N.; et al. FTY720/fingolimod increases NPC1 and NPC2 expression and reduces cholesterol and sphingolipid accumulation in Niemann-Pick type C mutant fibroblasts. FASEB J. Off. Publ. Fed. Am. Soc. Exp. Biol. 2017, 31, 1719-1730. [CrossRef] [PubMed]

127. Blom, T.; Back, N.; Mutka, A.L.; Bittman, R.; Li, Z.; de Lera, A.; Kovanen, P.T.; Diczfalusy, U.; Ikonen, E. FTY720 stimulates 27-hydroxycholesterol production and confers atheroprotective effects in human primary macrophages. Circ. Res. 2010, 106, 720-729. [CrossRef] [PubMed]

128. Miron, V.E.; Ludwin, S.K.; Darlington, P.J.; Jarjour, A.A.; Soliven, B.; Kennedy, T.E.; Antel, J.P. Fingolimod (FTY720) enhances remyelination following demyelination of organotypic cerebellar slices. Am. J. Pathol. 2010, 176, 2682-2694. [CrossRef] [PubMed] 
129. Sucksdorff, M.; Rissanen, E.; Tuisku, J.; Nuutinen, S.; Paavilainen, T.; Rokka, J.; Rinne, J.; Airas, L. Evaluation of the effect of fingolimod treatment on microglial activation using serial PET imaging in multiple sclerosis. J. Nucl. Med. Off. Publ. Soc. Nucl. Med. 2017, 58, 1646-1651. [CrossRef]

130. Cardozo, P.L.; de Lima, I.B.Q.; Maciel, E.M.A.; Silva, N.C.; Dobransky, T.; Ribeiro, F.M. Synaptic elimination in neurological disorders. Curr. Neuropharmacol. 2019, 17, 1071-1095. [CrossRef]

131. Di Filippo, M.; Portaccio, E.; Mancini, A.; Calabresi, P. Multiple sclerosis and cognition: Synaptic failure and network dysfunction. Nat. Rev. Neurosci. 2018, 19, 599-609. [CrossRef]

132. Di Filippo, M.; Sarchielli, P.; Picconi, B.; Calabresi, P. Neuroinflammation and synaptic plasticity: Theoretical basis for a novel, immune-centred, therapeutic approach to neurological disorders. Trends Pharmacol. Sci. 2008, 29, 402-412. [CrossRef]

133. Rossi, S.; Motta, C.; Studer, V.; Barbieri, F.; Buttari, F.; Bergami, A.; Sancesario, G.; Bernardini, S.; De Angelis, G.; Martino, G.; et al. Tumor necrosis factor is elevated in progressive multiple sclerosis and causes excitotoxic neurodegeneration. Mult. Scler. 2014, 20, 304-312. [CrossRef]

134. Takeuchi, H.; Jin, S.; Wang, J.; Zhang, G.; Kawanokuchi, J.; Kuno, R.; Sonobe, Y.; Mizuno, T.; Suzumura, A. Tumor necrosis factor-alpha induces neurotoxicity via glutamate release from hemichannels of activated microglia in an autocrine manner. J. Biol. Chem. 2006, 281, 21362-21368. [CrossRef]

135. Habbas, S.; Santello, M.; Becker, D.; Stubbe, H.; Zappia, G.; Liaudet, N.; Klaus, F.R.; Kollias, G.; Fontana, A.; Pryce, C.R.; et al. Neuroinflammatory TNFalpha impairs memory via astrocyte signaling. Cell 2015, 163, 1730-1741. [CrossRef] [PubMed]

136. Geurts, J.; Bö, L.; Roosendaal, S.; Hazes, T.; Danie, R.; Barkhof, F.; Witter, M.P.; Huitinga, I.; van der Valk, P. Extensive hippocampal demyelination in multiple sclerosis. J. Neuropathol. Exp. Neurol. 2007, 66, 819-827. [CrossRef] [PubMed]

137. Papadopoulos, D.; Dukes, S.; Patel, R.; Nicholas, R.; Vora, A.; Reynolds, R. Substantial archaeocortical atrophy and neuronal loss in multiple sclerosis. Brain Pathol. 2009, 19, 238-253. [CrossRef] [PubMed]

138. Dutta, R.; Chang, A.; Doud, M.K.; Kidd, G.J.; Ribaudo, M.V.; Young, E.A.; Fox, R.J.; Staugaitis, S.M.; Trapp, B.D. Demyelination causes synaptic alterations in hippocampi from multiple sclerosis patients. Ann. Neurol. 2011, 69, 445-454. [CrossRef] [PubMed]

139. Sicotte, N.L.; Kern, K.C.; Giesser, B.S.; Arshanapalli, A.; Schultz, A.; Montag, M.; Wang, H.; Bookheimer, S.Y. Regional hippocampal atrophy in multiple sclerosis. Brain 2008, 131, 1134-1141. [CrossRef]

140. Jurgens, T.; Jafari, M.; Kreutzfeldt, M.; Bahn, E.; Bruck, W.; Merkler, D. Reconstruction of single cortical projection neurons reveals primary spine loss in multiple sclerosis. Brain 2016, 139, 39-46. [CrossRef]

141. Vercellino, M.; Merola, A.; Piacentino, C.; Votta, B.; Capello, E.; Mancardi, G.L.; Mutani, R.; Giordana, M.T. Altered glutamate reuptake in relapsing-remitting and secondary progressive multiple sclerosis cortex: Correlation with microglia infiltration, demyelination, and neuronal and synaptic damage. J. Neuropathol. Exp. Neurol. 2007, 66, 732-739. [CrossRef]

142. Planche, V.; Panatier, A.; Hiba, B.; Ducourneau, E.G.; Raffard, G.; Dubourdieu, N.; Maitre, M.; Leste-Lasserre, T.; Brochet, B.; Dousset, V.; et al. Selective dentate gyrus disruption causes memory impairment at the early stage of experimental multiple sclerosis. Brain Behav. Immun. 2017, 60, 240-254. [CrossRef]

143. Rajendran, L.; Paolicelli, R.C. Microglia-mediated synapse loss in Alzheimer's disease. J. Neurosci. Off. J. Soc. Neurosci. 2018, 38, 2911-2919. [CrossRef]

144. Stephan, A.H.; Barres, B.A.; Stevens, B. The complement system: An unexpected role in synaptic pruning during development and disease. Annu. Rev. Neurosci. 2012, 35, 369-389. [CrossRef] [PubMed]

145. Lehrman, E.K.; Wilton, D.K.; Litvina, E.Y.; Welsh, C.A.; Chang, S.T.; Frouin, A.; Walker, A.J.; Heller, M.D.; Umemori, H.; Chen, C.; et al. CD47 protects synapses from excess microglia-mediated pruning during development. Neuron 2018, 100, 120-134.e6. [CrossRef]

146. Michailidou, I.; Willems, J.G.; Kooi, E.J.; van Eden, C.; Gold, S.M.; Geurts, J.J.; Baas, F.; Huitinga, I.; Ramaglia, V. Complement C1q-C3-associated synaptic changes in multiple sclerosis hippocampus. Ann. Neurol. 2015, 77, 1007-1026. [CrossRef] [PubMed] 
147. Shi, Q.; Colodner, K.J.; Matousek, S.B.; Merry, K.; Hong, S.; Kenison, J.E.; Frost, J.L.; Le, K.X.; Li, S.; Dodart, J.C.; et al. Complement C3-deficient mice fail to display age-related hippocampal decline. J. Neurosci. Off. J. Soc. Neurosci. 2015, 35, 13029-13042. [CrossRef]

148. Shi, Q.; Chowdhury, S.; Rong, M.; Le, K.X.; Hong, S.; Caldarone, B.J.; Stevens, B.; Lemere, C.A. Complement C3 deficiency protects against neurodegeneration in aged plaque-rich APP/PS1 mice. Sci. Transl. Med. 2017, 9, eaaf6295. [CrossRef] 